\title{
Exploring the Role of Mentoring in the Quality of Teacher Training in Ghana
}

\author{
Mohamed M. Bukari \\ (Ghana Education Service, Special \\ Education Division, Head Office, Accra) \\ Corresponding Author: \\ Ahmed Bawa Kuyini (PhD) \\ School of Health, University of New England, Australia \\ Email: kuyinia@une.edu.au
}

Doi:10.5296/ijld.v5i1.6822

URL: http://dx.doi.org/10.5296/ijld.v5i1.6822

\begin{abstract}
This study adopts a qualitative case-study method to examine the mentoring of teacher trainees in Ghana. Interviews with the trainee teachers and head teachers provide data on the process, the participants' experiences and perceived benefits and challenges of the program. Recommendations for improvement are provided.
\end{abstract}

Key words: Ghana, Teacher Training, Mentoring Trainee Teachers, Mentoring \& Teacher Quality

\section{Introduction}

Today, all over the world, governments want teachers to become more effective, particularly in the light of increased global competitiveness, and the necessity of economic and educational reforms. Teacher Education is the most important aspect of a nation's education system. It is this segment of the educational system that provides the greatest human resource, because every school needs a teacher. It has been argued that one specific condition for development is education and 'the teacher is the ultimate defender of its reality' (Adegoke, 2003). According to Furlong (2000), one significant way of influencing the skills, knowledge and values of teachers is to change the form and content of their initial training.

Research into the cost of educational programs for teacher-training in selected developing countries indicates that teacher education program arrangements are unpredictable and irregular, which create an unstable learning environment for teacher training (Lewin \& Stuart, 2003). In view of this, the exploration of new models to improve the quality of teachers training has taken place in many developing countries.

\section{Statement of the Problem}

Following decades of change in initial teacher education, there is concern in Ghana about how institutions are preparing future generations of teachers to face the challenges of the $21^{\text {st }}$ Century. This concern emanates from the fact that many teachers lack adequate skills when they come out of training (Agbenyega \& Deku, 2011, Kuyini \& Desai, 2007, 2008).

Until 1987 Teacher Education in Ghana did not attract much attention. Very little was done in terms of structural and curriculum reforms. However, following the reform of pre-tertiary education in 1987, it became necessary to reform teacher education in order to address the demands of the new education program and to address problems created by years of neglect of 
the sector resulting from a fall in the real value of government spending on education (MOE, 2004). The Government implemented the new teacher training program called In-In-Out program in 2004 with the aim of ensuring that new teacher trainees will receive mentoring as way to develop adequate practical skills before becoming fully fledged teachers. However the economic situation in Ghana with limited resources often affects all government programs and it is often unclear whether or not the objectives of new programs are being achieved. Against this background, this study explored the concept of internship or mentorship, which is part of the 'In-In-Out' program to determine the role that this could play in initial teacher training in Ghana.

Reflecting on teacher training in Africa, some have argued that teacher education is a weak intervention that is incapable of overcoming the powerful influence of the teachers' own personal schooling or the impact of experience on-the-job. This assertion of weakness is evidenced in the link that has been made between poor quality teaching and consistently poor performance of students at the Basic Certificate Examination (BECE) across the country over the last decade (Kuyini, 2013). In addition, various claims have been made about the strengths and limitations of the current In-In-Out teacher-training program. One aspect of the In-In-Out program that has not been properly investigated is the role of mentors in the "Out" segments of the program. Therefore investigating how the new Diploma of Education program enhances teacher quality in the "Out" segment with particular focus on the mentoring role is necessary. Indeed, generating systematic data about the impact of training on trainee teachers' ideas and practices in this segment has the potential to guide reform in the teacher-training curriculum.

\section{Aims of Study}

To gain insights into the factors which shape the identity, commitment and competence of newly trained primary and junior secondary school teachers, this research started with some simple questions:

- What do the trainees experience during their training, and how do they feel about its value in terms of enabling them to perform effectively in the classroom?

- What are student teachers' experiences about the mentors and mentoring process?

- What are the benefits of the processes?

- What can be done to improve the process?

This study is significant because very little research has been conducted on this specific topic in Ghana, since the program was introduced in 2004. Therefore, this research was intended to inform and enrich the debate about how teachers could be prepared for their work. Finally, it has generated useful information for policy makers, educationalists, students, planners and other development partners and stakeholders in education.

\section{Literature review}

Teacher training is about helping teacher trainees to understand the philosophy of teaching, and acquire the knowledge and skills of teaching to a level that allows them to practice effectively in schools. Although all teacher-training programs are built around this goal, some institutions do not necessarily achieve their goals for various reasons. Variations in quality of teacher training have got to do with the chosen curriculum and its design, different conceptions of the best way to help teachers learn how to teach and/or the different approaches and alternatives to teacher preparation. 
Calderhead (1989) stated that student teachers might learn to teach in numerous ways because different types of learning may occur in different phases in a teacher's career. Using multiple theories from different perspectives, Donald Schon $(1983,1987)$ asked a critical question: how do people learn to become teachers? This question requires educators to think about where the actual knowledge, skills, and understanding required by the student teacher lie. It also means accounting for the people involved in giving this training. In other words, who is best placed to develop these aspirant teachers? And by whom may the students' learning be assessed? Putting these questions in context, the study defines and explains some of the key concepts and principles such as professionalism, mentorship, and partnership, and how they relate to the process of teacher preparation. These questions require a review of the notion of teacher development.

\section{The Conventionalised Notion of Teacher Development}

The notion that teachers can be prepared to teach leads to the question what set of ideas could be used to influence a better way of preparing teachers? This question helps us to account for some of the concepts and principles about the patterns of learning to teach. Feiman-Nemser (2000) lists five dimensions as the ways in which the teachers' preparation can be conceptualised: (a) Academic- teacher preparation as an academic activity (b) Practicalfocuses on the elements of craft, technique, and artistry that skilful practitioners reveal in their work. (c) Technological; focuses on knowledge and skills of teaching (d) Personal - places the teacher-learner at the centre of the educational process and (e) Critical/social; teacher preparation combines a progressive social vision with a radical critique of schooling.

These dimensions of teacher preparation also all lead to the idea of models of training Cognitive Apprenticeship, Competency, Performance, and Cognitive models.

According Collins, Brown, and Newman (1989) Cognitive apprenticeship is an experiential learning situation in which the teachers think aloud, so that apprentice teachers cannot only observe their actions but can also "see" how they work through particular problems or tasks. Critics (e.g. Arnstine, 1975; Wilson, 1975) argue that apprenticeships encourage imitation rather than understanding and foster the maintenance of existing standards and practices.

The Competency model stipulates the notion of teacher trainees achieving a series of competences. It attempts to combine utilitarianism (focusing learning on what is useful) with rationalist or scientific principles (Carr \& Kemmis, 1986).

The Performance Model focuses on competence in the performance of complex, technical specialised and professional work activities, including those involving designing, planning and problem solving, with a significant degree of personal accountability (Furlong \& Maynard, 1995; Jessup 1991). The model is criticised as behaviourist in outlook, reductionist in its view of teaching and functionalist, where the teacher is seen as a natural expert (Marshall, 1991).

The Cognitive model places greater emphasis on knowledge and understanding instrumental in action and places less emphasis performance. Professionals, according to the cognitive model need to develop certain habits of mind, including the ability and commitment to critically examine their own practice; in other words, they need to learn to reflect. This idea is linked to the notion of Reflection in Action and terms such as 'Reflective practice', 'Inquiry oriented teacher education', 'Teacher as a researcher, 'Teacher as a decision maker'. 'Teacher as professional' and 'Teacher as problem solver'.

Schon $(1983,1987)$, argues that the relationship between professional knowledge and action has been seen and understood in terms of technical rationality. Professional activity has been 
regarded as a process of instrumental problem solving 'made rigorous by the application of scientific theory and technique' (1983: 21). He goes on to say that in this instance professionals have been seen as 'experts', in that they posses a body of exact knowledge which they 'apply 'in a rule-governed way to the real world. Schon argues that the contemporary professional may have a body of specialised knowledge, but that she or he does not simply 'apply' it in a rule-governed way. Whether or not one's teaching is raised to the level of consciousness, always involves a complex 'artistry'. In addition, Schon argues that this is not as simple as a process of 'applying' this knowledge to a given situation. The teacher does not try to fit a group of pupils rigidly into some kind of pre-existing pattern of understanding that will simply tell him or her what to do. Rather, past experiences are used as a metaphor or exemplar (Schon 1983: 131).

\section{Teacher Preparation and the Concept of Mentorship}

To prepare teachers to teach means considering all of the best avenues through which students can develop the cognition, experience and skills of their profession (teaching). Closely linked to this are questions about how people learn to become teachers and what the relationship is between those who provide the training and those who receive it. This leads to consideration of the concept of partnership with special reference to the role of mentoring in teacher preparation.

The term mentoring describes 'the support given by one (usually more experienced) person for the growth and learning of another, and for their integration into and acceptance by a specific community' (Malderez, 2001, p. 57). It is 'a particular mode of learning wherein the mentor not only supports the mentee, but also challenges them productively so that progress is made' (Smith 2007, p.277). Mentoring involves guidance and suggestion, as well as the development of autonomous skills, judgments, personal and professional mastership, expertise, trust and the development of self-confidence over time (O’Brien \& Hamburg, 2014).

In the last two decades school-based mentoring has become an increasingly important component of the process by which student teachers begin to learn how to teach. Not only are different forms of mentoring used in different countries, but several studies have focused on the role of mentoring in teacher education (Hagger et al, 1995, Heirdsfield, Walker, Walsh \& Wilss, 2008; Edwards 1997, Sundli, 2007). In teacher education, mentoring is seen as 'complex social interactions that mentor teachers and student teachers' construct and negotiate for a variety of professional purposes and in response to the contextual factors they encounter' (Fairbanks, Freedman \&Kahn, 2000, p.103).

Mentoring has been accepted as an effective method of preparing the student teacher to enter the teaching profession (Furlong, Chitty, Barrett, Barto \& Miles, 1994; Odell \& Ferraro, 1992; Sundli, 2007), since it helps the student teacher not only to easily take the full responsibilities of the classroom, but also to serve his/her pupils effectively. Mentoring is also mutually beneficial for mentors and mentees (Hall, Draper, Smith \& Bullough Jr, 2008; Heirdsfield, Walker, Walsh \& Wilss, 2008). According to Lai (2005, p.12) '....mentoring plays an important role in enhancing novice teachers' opportunities to learn within the contexts of teaching'. Thus, mentoring in specific context not only allows student teachers to acquire context specific knowledge but also develop situation-based skills, which can be transferred to similar future situations in that context. For the reason that teachers need to learn to teach in a particular context (Feiman-Nemser, 2003) and specific mentoring will occur that is dependant on the contextual circumstance (Hudson, 2004), each educational jurisdiction will have different forms and expectations of mentoring. 
Within the context of Initial Teacher Education (ITE), in the UK, Tomlinson (1995) defined mentoring as 'assisting student-teachers to learn how to teach in school-based settings' (Tomlinson, 1995, p. 7). According to such a definition, 'mentoring' in ITT is undertaken not merely by teachers holding the formal title of 'mentor' or 'teacher-tutor' but also by other teachers whose advice and support may be sought or whose teaching and interactions with pupils may be witnessed by student teachers or trainees.

Sundli $(2001,2007)$, writing on the Norwegian experience, sees mentoring as having two parts - the students' participation in teaching activities at school (situated learning), and mentoring as conversation between the mentor and the mentee. Lai (2005) echoes these definitions stating that mentoring has three components /dimensions - relational, developmental and contextual. Relational refers to the relationship between mentors and mentees. Developmental refers to how mentors and mentees develop personally and professionally whilst aiming towards particular goals. Contextual, on the other hand, focuses on cultural and situational features of the mentoring setting. Lai notes that it is these three components, which create and impact upon a mentoring relationship (Cited in Ambrosetti, \& Dekkers, 2010, p.43).

Mentors need special skills in order to help student-teachers in their pursuit of acquiring the required training (Furlong \& Maynard, 1995) and in the case of teaching it comes, among others, with years of experience. Hobson (2002) argues that mentoring is so crucial to quality teacher training and therefore, all teachers in schools which participate in ITT should be aware of the importance of mentoring and should have some ideas about how to perform such a role effectively.

The use of mentoring in ITT in the UK, USA and Norway has been influenced by new thinking about teacher training and corresponding changes to teacher training policies. In the England and Wales the place of mentoring in ITT became pivotal given legislative changes, notably the DFE Circular 9/92 (DFE, 1992), which directed that student teachers on postgraduate training courses spent two-thirds of their courses in schools.

In Norway, mentoring took a different form and focus from the early half of the 1990s. According to Sundli (2007), in Norway mentoring was seen as an important approach for securing and enhancing quality....most of the teacher colleges in Norway have adopted a strategy for supervision based on Handal and Lauva ${ }^{\circ}$ s (1987)'s Promoting Reflective Thinking. ....This mentoring strategy emphasises pre-supervision, meta-communication about situation and role, exemplary analysis, by attempting to show the general through the specific or special, and promote a socially secure but a professionally challenging situation" (p.203).

Slobodan (1986) stated that 'real life skills are usually learnt with the aid of some form of coaching', and argued that appropriate feedback on practice, which he characterised as 'knowledge of what your actions achieved', is 'essential to skill acquisition' (Slobodan, 1986, pp. 32-33). Developing the point and also drawing on the work of Norman (1978), Tomlinson states that:

"The acquisition of practical capability requires cycles of plan-attempt-feedback-replan, a process which when done with the same action unit tends to produce a gradual tuning that makes it more accurate, economical and intuitive" (Tomlinson, 1998, p. 13 taken from Hobson, 2002, p.6)

Early notions of teacher development in the UK and Ghana, whose programs were inspired by that of the UK, tended to be based on the assumption that the 'beginning teacher' held the 
requisite subject knowledge and that the training would consist of a mixture of 'theory -lectures' at the Higher Education Institution (HEI), combined with an apprentice-like attachment to an experienced teacher or teachers in school. The theory aspect of the training was often based on the education 'foundation disciplines' of philosophy, history, psychology and sociology (Alexander, 1990; Christie, 2003). However, as part of the increased recognition of the role of mentoring in teacher training, many countries including Ghana now emphasise mentoring in their teacher training programs. In Ghana, which is the focus of this study, the idea of mentoring is rooted in the desire for quality teacher training and generally designed around practice in local schools close to the teacher training institution. Therefore, mentoring is informed by context situated learning.

\section{Initial Teacher Education in Ghana}

Teacher training in Ghana began with a four-year teacher training program, followed by twoyear Certificate-B and Post-B programs that were designed to meet the growing need for more teachers in the country. Later, the Certificate-A (Post-Secondary) and the two-year Specialist Programs were introduced. In 1978, all of these programs were phased out giving way to a 3-Year Post-Secondary Teacher Training Program, which has since undergone different reforms. The rationale for the various restructurings was, first and foremost, to produce enough teachers to reduce the high numbers of untrained teachers in the system, and secondly, to upgrade the qualifications of teachers to meet the standards required to teach (Akyeampong, 2003).

In 2004, teacher-training colleges were converted into Diploma awarding institutions with a new structure that still operates today. The current structure of basic teacher training is a three-year pre-service Diploma in Basic Education program, which is divided into Program A and B to prepare teachers for teaching in primary and junior secondary schools respectively. The strategic mission of teacher training in Ghana is to "provide comprehensive Teacher Education programs that would produce competent committed and dedicated teachers to improve the quality of teaching and learning in Ghanaian classrooms" (TED, 2003). To achieve this vision, the Government of Ghana reformed the ITT program, creating an innovative mentoring component in "Out" stage of the new teacher-training program dubbed "In-In-Out programme".

According to the Teacher Education Division (TED, 2003), the In-In-Out Scheme is a reconstruction of the existing teacher curriculum. It was initially designed for three-year Post Secondary Teacher's Certificate-A, which was later (in 2004) upgraded to the three-year Diploma program as part of a national policy strategy to raise teachers' entry-level skills. The first two years are spent on the college campus, when teacher trainees are taught a range of subjects including Mathematics, English, Science, Vocational skills, Social studies, Music and dance, Religious and moral education, Physical education, Ghanaian language and Educational studies. The rationale for this taught-program is to refresh the knowledge of the teacher trainees and equip them with the requisite knowledge, which they need to use when they go for the one-year practicum in the 'Out' -segment in their third year. In the first two years (In-In Stage) the trainees are 'filled' with a large amount of subject content knowledge to which they will be expected to 'apply' the 'theory' of teaching during their practicum and also when they become fully- fledged teachers. In the 'Out" stage, trainees spend the full year in a school under a mentor.

\section{Context of the Study:}


The case study institution is one of the teacher training colleges located in the Upper West region of Ghana. It was established in the early 1980s as a co-educational institution. The college draws its students mostly from the northern Ghana and a few from the southern part of the country.

\section{Method}

The larger study from which this paper is drawn used a qualitative Case Study approach to explore the various roles played by stakeholders (tutors, mentors, teacher-trainees), and the Ghana Education Service District Directorate in shaping the outcomes of teacher preparation at the Training College. Qualitative case study is an approach to research that facilitates exploration of a phenomenon within its context using a variety of data sources (Merriam, 1988). It is characterized as particularistic (focus on a particular instance or situation), descriptive (end product is a rich, "thick" description of the phenomenon under study), heuristic (clarify the reader's understanding of the phenomenon under study) and inductive (generalizations, concepts, theories, hypothesis usually come at the end of the study as emerging concepts). Qualitative Case studies are differentiated from other types of qualitative research in that they are intensive descriptions and analysis of a single unit or bounded system (Merriam, 1988). This ensures that the issue is not explored through one lens, but rather a variety of lenses, which allows for multiple facets of the phenomenon to be revealed and understood. In this case study, the focus was on the training program, especially the learning experiences of student teachers at college and during the "Out" segment of the In-In-Out program, when trainees teach under a mentor in a school.

The reason for choosing a qualitative Case Study approach was that the approach is ideal for a "holistic in-depth investigation of the phenomenon in the real-life context" (Yin 1994; Stake, 1995). The approach made it possible to explore and understand the technical and social negotiation processes that shape teacher preparation at the college through a variety of data sources, including mentors and mentees. The approach was appropriate, in that it allowed for an in-depth exploration of the key events and activities in teacher preparation including how the students learn to teach, effective partnership practice and the mentoring process, the support provided to student teachers and the perceptions of the head-teachers regarding the process (Creswell, 2003).

\section{Population and sample}

The target population was all student teachers at the selected college, tutors of the college and head-teachers (mentors) of primary schools, which had taken on student teachers for practicum. A total of 18 teacher trainees (Mentees) from the College and eight headteachers (Mentors) from the local schools participated in the study.

\section{Sampling}

The population of potential participants was large and so a purposive sampling technique was use to select participants to represent the relevant stakeholder groups- student teachers and headteachers. In this case student teachers in the "Out" stage of the In-In-Out training program as well as head teachers in whose schools the student teachers had been posted over the years were targeted for selection. The student teachers were selected by convenience sampling whereby all potential participants who signed consent forms to participate were selected. The heads of schools that also completed consent forms were included in the study. A total of 18 student teachers Mentees) and eight headteachers (Mentors) were selected. The student 
teachers were included as participants in the interviews for the simple reason that they are the direct consumers of the program. They are the beneficiaries and also the trailblazers of the Diploma in Basic Education Program, and are therefore in a key position to give a fair and true account of whether or not the program is beneficial to them. The headteachers (mentors) are central figures in the mentoring process and could provide the mentors' view about the mentoring program.

\section{Instruments:}

As a semi- structured interview, interview schedule was developed with key questions around the following:

1. What have you learnt in teacher training,

2. How do you see the monitor process?

3. Is it beneficial?

4. What are the challenges?

The questions asked in a semi-structured interview were flexible, allowing for in-depth probing, clearing up misunderstandings and testing of the limits of the interviewee's knowledge (Cohen \& Manion, 2004). The questions were also specific enough to elicit relevant responses from the interviewees and allowed the interviewer to evaluate the adequacy of his or her responses (Miller \& Cannel, 1989).

\section{Data collection:}

Prior to data collection, letters were sent to the Ghana Education Service and Principal of the target to seek permission for the interviewer to gain access to the school to interview both the student teachers on-campus and those who were off -campus undertaking teaching practice in the primary schools. Student teachers were asked to sign consent forms and only those who consented were interviewed. Letters of invitation to participate and consent forms were also sent the local schools where students undertake their teaching practice under mentors.

A research assistant was engaged to help with the conduct of the interviews after clearance from the Ghana Education Service and the Principal the college. The researcher was equipped with a cassette tape recorder, audiocassettes for recording, and a printed interview schedule for each group of respondents. The interview sessions were recorded with the permission of the participants. Each interview lasted 30 minutes.

\section{Data Analysis}

Having transcribed the interviews, the data was analysed through the following steps:

- Careful reading of the transcripts of interviews with the participants

- The views presented by participants from the transcripts were identified around a number of themes.

- The themes were selected to provide reliable and accurate views concerning the issues that arose pertaining to the research questions.

- Using these themes as 'organising categories', a more detailed re-analysis of the transcript was carried out, looking specifically for comments or details that related specifically to the themes identified by the initial analysis.

The key themes that became apparent in reading the interviews, and which were significant in terms of the research questions, formed the basis of the analysis of the paper. Extracts from the interviews were placed under themes, which related to questions posed by the study. 


\section{Results}

The results of the study are presented in line with the key research questions. There is a particular focus on what the student teachers encountered as a result of the introduction of the 'Out' segment of the Diploma in Basic Education (DBE) program, and on the mentorship approach in which mentors are involved in supporting the training of the trainee teachers (mentees). The mentees are student teachers that are sent to schools as part of their training to gain experience in the classroom (on-the job-training) as an effective method of training teachers for quality education in Ghana. Many researchers, for example Lawlor (1990) and O'Hear (1988) have advocated that the training of teachers should involve putting them in the classroom under the supervision of senior members of the teaching profession. It was unanimously agreed by Government and professional bodies that the introduction of the Diploma in Basic Education Program was necessary and that if the necessary inputs were provided, this could bring about the desired level of teacher preparation in the teacher training colleges in Ghana. This report is about how the mentees and mentors saw the mentoring process.

\section{What do the trainees experience during their training?}

The student teachers (Mentees) responded to the question around the kind of training they received in college before their encounter with school-based practical teaching. The responses from all eighteen mentees interviewed indicated that they spent the first two years termed "In-In" segment in college and the final ("Out") year in community (village) school. In terms of actual training content, the respondents said that they received a lot theoretical knowledge. Their responses suggested that they were taught many subjects as well as theories of teaching prior to going on practice in the "Out" stage. To this, one mentee said:

The training I received while in college included Religious and Moral education course and subjects knowledge. Other academic courses like child psychology gave me a lot of ideas with practical knowledge about how to handle children. The problem is that it was too much to learn, I feel or I think, it is too much overloaded.

Another respondent said" "We receive most of our training on the principal ideas or theories of how to teach through advice and observing our mentors, on many issues ranging from lesson planning, writing lesson plans, lesson delivery, how to deal and maintain discipline in the classroom, how to engage children with challenging behaviour".

However, some participants also mentioned subjects they felt did not meet their expectations. One of such subjects mentioned by all mentees was Information and Communication Technology (ICT), which they said was too practical, laborious and needed constant learning.

\section{What are student teachers' experiences about the mentors and the mentoring process?}

In answer to the question of how the teaching/ mentoring program evolved, the students said that in general they were designated to a class to be mentored and monitored by both the regular class teacher as his/her mentor and occasionally supervised by tutors of the college.

\section{Mentees' teaching practice during the "Out" Stage}

Some respondents said that the demands of teaching were appropriate and they were able to me the expectations of their practice. Some students on the hand expressed dissatisfaction with the teaching and felt inadequately supported. Explaining what they did not like about the teaching practice, one of the mentees said:

Daily diaries and study cycles were additional things we were required to do that were 
both boring, unpleasant and time consuming. To me, these do not in any way add anything to the repertoire of knowledge.

These links up with the problems associated with teaching during the mentoring process. Explaining the problems they experienced as mentees in their schools of practice, one of the mentees said:

".... some of the teachers assumed or pretend to assume that mentees are substitute teachers. Therefore they leave the class entirely in the hands and care of the mentees".

Other respondents mentioned the following:

1 We are left alone in the classroom with nobody to consult.

2 The children caused mayhem by changing marks that were recorded in their exercise books especially when they scored zero.

3 Sometimes the communities were antagonistic towards us.

4 We had the problem of non-availability of syllabuses, especially for English, Mathematics and accommodation among others.

Another problem identified relates to the use of lesson plans and using teaching methodology. According to the mentees most of the mentors, with whom they worked, were not themselves systematically using lesson plans, nor did they seem to teach according to any specific methodology. In other words, their lessons did not follow a formal regular structure (i.e. lesson objectives, starters, main task and plenary). Also, the trainee teachers felt that they were often being used by the mentors simply as an extra pair of hands that could relieve them of some of their heavy workload. There were even examples of the mentors becoming truants and sometimes refusing to come to school when trainee teacher were there.

The problems catalogued above reflected the serious challenges associated with the training program and the mentoring of teachers. The study revealed that the supervisory mechanism put in place to support the mentees under the training program is weak. This is reflected in the words "We were left alone in the classroom with nobody to consult".

\section{What are the benefits of the process?}

For the mentees, both the training content at "In-In" stage and the mentoring program at the "Out" stage had benefits. The mentees also responded to the benefits of the theory lectures, almost all of those interviewed were affirmative of their usefulness to the overall preparation before the "Out" segment. One mentee commented:

The methodology aspect is very useful to me, especially the vocational skills, which assisted me to prepare my teaching and learning materials.

All of the mentees interviewed also stated that they benefited greatly from the assistance offered them by the mentors in the form of lesson planning and delivery, and more importantly words of advice. One mentee said:

My mentor helped me whenever I needed assistance. They helped me to prepare my lesson notes whenever I was in difficulty, told me to make sure Teaching and learning material were ready before I embark on teaching. He also asked me to dissociate myself from canning children but keep the language at the level of the pupils. 


\section{What can be done to improve the process?}

When asked what they would have done differently if they were the organisers of the program, one mentee said:

I would have called for the withdrawal or scrapping of the use of daily diaries because they waste a lot of students' time and also reduced the number of subjects to a minimum of seven so that it would be manageable for students to study very well.

From the foregoing, it is clear that mentees are not too pleased with the curriculum of the new teacher reform program in Ghana. The responses of the mentees confirm this fact when they complain about the work load and irrelevant subjects.

\section{Mentors' Perspective about Mentoring}

The purpose of these interviews was to elicit the views of the head-teachers, as key players in the mentoring process, concerning their experiences of the mentoring process. Their responses fit in with the questions of what the mentees experience during the mentoring process, the benefits of the processes and what can be done to improve the process?

The head teachers were asked about their perceptions of the performance of trainee teachers. Commenting on the differences between the performances of trained teachers and the trainee teachers (mentees) on their approach to teaching, one head-teacher said:

Both the trained as well as the trainee teachers do teach as expected. The preparation of lesson notes by trainee teachers however, is less professional. Most mentees are often assisted in their lesson planning.

Generally, the mentees need a lot more training to enable them to teach effectively with some orientation and lesson observation from their mentors, they will eventually pick up the skills.

In terms of the performance of mentees, the Head teachers were of the view that the mentees performed well under supervision. What this means is that given the right assistance and guidance by head teachers and mentors, the mentees could perform well on the job upon completion.

Responding to how the student teachers contribute to the academic work in the classrooms and to bring about an improvement in the performance of the students in the school, one head teacher said:

The mentees complement the teacher's efforts in the class as they assist the class teacher in teaching the pupils. When they are sent to their schools of attachment, they look at what the trained teacher does by observing. The mentee observes the class teacher who mentors him or her and is supposed to be his or her guide, as a helper, and a source of advice.

The role of the head teachers in the trainees' development while they are in their schools is crucial. On what exactly Head-teachers do, especially when they discover that the mentee is struggling. One headteacher said:

The onus lies on us, the heads, to help the mentees and newly trained teachers to improve their competences by organising a kind of in-service education training for them to enable them to improve upon the methods of teaching. These days, head teachers are given a 
'capitation grant'. Head teachers have the right to use the grant not only for logistics but also for organising training if they find that teachers are not competent in the basic skills of teaching. Sometimes we ask for reinforcement from other resource persons when we have many similar cases.

Asked whether they are satisfied with the standards and quality of the mentees and or newly trained teachers' performance, one head teacher said

From my routine observation visits to classes, I have gathered that out of the four mentees and two new teachers on my staff, three of them are classic in their lesson delivery and class control with the fourth fairly good, while one of the two newly trained teachers also seems to know what he is about. The fourth mentee and the other new teacher have not demonstrated much professional competence yet. Almost all the mentees are diligent in their work; they write comprehensive lesson notes and display all the professional competencies.

Two head teachers said that they could not generalise, but were largely satisfied with the quality of the newly trained teachers as well as the mentees.

From the responses that others gave, there were indications that quite a good number are very good, but as time goes on, they good ones are influenced negatively by the old ones. Responding to this, one head teacher said:

Normally the new teachers that I have supervised in the several schools where I have been the head have proven to be professionally good. With time they get caught up either with lust for money and therefore complain about the level of salary being inadequate which is not commensurate with the work that they do.

On whether there is need for change in the structure of the teacher-training program, some of the heads had this to say:

Teachers that pass through the system, except for a few, seem to be doing well at their own level. However, what I want done to the structure is that adequate practical training should be given to the teachers before they go on to practice teaching and consequently enter the field as qualified teachers.

Other head teachers had expressed some other opinions though not in conflict with the first group but seem to have a divergent dimension. One of the head teachers had this to say:

Ghana Education Service (GES) and Teacher Education Division (TED) should re-align their policies towards teacher education such as the entry requirements, number of years of the programme and the syllabuses. Although subject knowledge is very important for delivery of lessons in class, I think much emphasis should be placed, on the practical aspect of teaching...".

When asked about the challenges they face in preparing teachers adequately for their profession, one head teacher had this to say:

All members of staff are under my tutelage and I try as much as possible to synchronise their welfare with professional issues. I also observe lessons delivered by my staff in their various classrooms to assess and query members who apparently fall short of their content and methodology and commend those who are outstanding. 
Another head teacher in responding to the question of the importance of the support they offer in the training of teachers to be competent in their profession said:

I make available syllabuses and all other necessary things that are within my capacity. Unfortunately members of staff have a misconception about this capitation grant whilst some think it should be treated as a welfare fund others think that the heads use it for personal things. Amidst this mixed feeling, I always make the use of it as transparent as possible by involving most of my staff and school management committee as well as the executive of the parent's teacher association in the budgeting and purchase of teaching and learning materials.

\section{Discussion}

\section{What Do Trainees Experience?}

Looking at the view points of the participants (tutors, mentors, teacher trainees, Principal etc.) who are directly involved in the practical training of the teacher trainees, the following ideas emerged as strong opinions which either complement or conflict with standard practice. From the different groups, the program is divided into two phases. The first phase involves two year preparatory training which is termed the "In-In" stage and the final year, called the "Out" stage, which is spent in a community (village) school teaching a designated class, monitored by (mostly) the regular class teachers who should act as their mentors. The mentees (teacher trainees) in the 'Out' program also have occasional supervisory visits from the tutors of the college.

In the first preparatory phase, the teacher trainees learn about the theories and principles of teaching, which they will use later in their practical training. During this phase of their training, the student teachers are assessed in various ways, such as class tests, quizzes, assignments and semester examinations, which are mostly based on the curriculum. The responses suggest that the Diploma in Basic Education (DBE) program is overloaded with content and is overly examination oriented. Some subjects such as ICT were perceived as not beneficial, but it appears from the responses that these perceptions may be due to how the subjects were taught.

\section{Mentoring process}

The study confirmed the fact that during the "Out" stage of the teacher training program student teachers (mentees) spend the entire year in local schools under a mentor. As indicated in the results section, the mentees reported that they received support from their mentors but also revealed some issues with the mentoring. One of the issues related to the non-systematic use of lesson plans, not teaching according to any specific methodology, not following a formal regular structure (i.e. lesson objectives, starters, main task and plenary) and using mentees as an extra pair of hands.

Despite these difficulties the trainee teachers agreed that the school placements have some benefits, such as; the vocational skill which assisted teachers to prepare their teaching and learning materials from the first phase of their training at the college. They also agreed that the "Out" segment of the program training exposed them to a range of issues such as lesson planning, writing lesson plans, lesson delivery, how to deal with and maintain discipline in the classroom, and how to engage children with challenging behaviour.

For the purpose of discussion on the benefits of the mentoring program, four main issues emerged:

1. Mentees seeking advice from mentors 
2. Communication gap (between mentors, mentee and the college)

3. Differences of opinion between mentees and mentors

4. Whether the mentor role is understood.

Firstly, in the interview responses there was the use of the word "advice" on many occasions. These responses appeared to suggest that mentees were seeking advice and guidance from mentors and this reinforces the need for experienced people (mentors) who can provide a model to be emulated by the beginning teacher (Bozeman \& Feeney, 2007; Wilkins, 1992). It also points to the Norwegian conceptualisation of mentoring as a process where mentors and mentees engage in conversation as defined by Sundli (2007). This practice also seems to adopt Arnstine and Wilson's (1975) concept of apprenticeship; the apprenticeship model also encourages novices to learn from the practices of mentors.

Slobodan (1986) observed that 'real life skills are usually learnt with the aid of some form of coaching', and argued that appropriate feedback on practice, which he characterised as 'knowledge of what your actions achieved', is 'essential for skill acquisition' (Slobodan, 1986, pp. 32-33). Thus learning how to teach must involve the students' consistently exploring their own and other people's practices in order to reveal the intellectual, moral and other assumptions on which their learning is based. Mentors need special skills in order to help the student teachers in their pursuit of the needed training (Furlong \& Maynard, 1995) though there is no evidence that these teachers acting as mentors in Ghana have themselves acquired the requisite skills.

Ball (1987) suggests that this kind of practice does not necessarily preclude a consideration of the underlying principles or the development of a conceptual understanding of the learning involved. In other words, this model seems to emphasise "the practical experience in doing it" over and above "understanding the process of teaching". The major limitation of this model is that it produces teachers who are able to teach but who do not understand what they are doing (McElvogue \& Salters, 1992). This therefore means that besides the skill of performing the art of teaching, there is the need for content and understanding which underline these principles.

Again, if teaching is said to be a profession (teachers taking decisions on behalf of and in the best interests of their clients; in this case the parents, council, government, etc), then training should involve the need for teachers to exercise judgment and develop ability and commitment, to examine and reflect on their own practice.

Some have raised the question of whether the mentoring model is an appropriate one for beginning teachers, since it implies that the ability to teach is one's ability to perform specific tasks such as lesson planning, i e writing lesson plans, lesson delivery, how to deal and maintain discipline in the classroom, and how to engage children with challenging behaviour successfully. While these are activities which are measurable, observable, with specific competences that are attainable and, therefore, can be assessed by simply ticking elements performed on a check list they may represent a simplification of the teaching task. This view Elliot (1990) argues, is inappropriate to conceptualise professional competence in terms of a string of behavioural competences whose performance is measurable. This model also seems to place more emphasis on performance instead of cognitive ability in these activities. Relating this point back to the point that the teacher trainees here were not learning as effectively as they ought to, through observation and advice it is important that the teacher trainees are given the opportunity to coordinate and develop their own knowledge, understanding and attitudes alongside the practical skills that enable them to understand both the content of their teaching and the processes (McElvogue \& Salters, 1992). It seems then that the trainees are neither 
enjoying the environment nor the support, which would allow them to take full advantage of the school placement. However, the distinction made by writers such as Sundli (2007), which proposes that mentoring takes out the assessment component associated with supervision could imply that mentoring is not clearly defined in the Ghanaian context.

The way forward is for the mentors and schools to create an enabling environment, which will provide prospective teachers with the support or means (through situations where there are no "right" answers) to develop themselves. It is believed that by trying out multiple interpretations and considering alternative courses of action, these prospective teachers will be helped to recognise and even accept the endemic uncertainties of teaching, as well as develop the specific skills relevant to the job.

The interviews produced ample evidence that there are communication gaps between the tutors, mentors and teacher trainees on many issues. For instance, the program is run in a discrete way with separate and distinctive roles in each phase in such a way that the tutors are in absolute control of what goes on in the colleges. When teacher trainees leave the college, their progress becomes the responsibility of the in-school mentors who have no connection with the tutors except when they come to the schools to assess the trainees. Trainees have no means of contacting tutors whilst in schools, and the mentors have no opportunity to interact with the tutors except when they come to their school for assessment.

This clearly shows that the coordination of teacher training by the key players is based on an approach which concentrates only on the structures which define teacher education. The problem with this approach is that although it may save some money for the parties involved, the poor impact that this approach brings is the real cost to those at the cutting edge of education - the tutors and students - who find themselves "forced into a simplistic structure which does not map on to the complex world they actually experience" (Edwards et al., 2002. p. 131). Also because this approach operates strictly on complementary partnership principles, the program lacks real integration, where the expertise of the schools and college staff are pooled together and deployed in all aspects in order to reinforce the program. Poor communication also contributes to a lack of consistency and, therefore, it is difficult to ensure quality control.

Thinking in line with Furlong and Maynard (1995), the school attachment component works well depending on the kind and level of interaction that will flow among all players and resource persons. Thus communication is an important tool in the success of partnerships (between training institutions and schools). The literature identifies three main types of communication: administration communication; interpersonal relations, relationships between tutors, mentors, mentees and shared understanding between the partners (training institutions and schools).

Perhaps Ghana should consider using the Norwegian and /or University of Manchester model of partnership. The model, which emphasises all three forms of communication, (Administration communication; Interpersonal relations, and the relationship between the tutors, mentors and trainee teachers) has received praise from the UK Office of Standard for Education (OfSTED) for involving the mentors and the schools in the various steps of the practical development of the program. The University of Manchester does this in a variety of ways, by (email, telephone, letters, reports, verbal communication etc), constantly to link the major players involved in the practical training of the student teachers; and involving the mentors in some of the most traditional activities of tutors such as the process of recruiting 
students to the course. They also involve mentors in interviewing the students during the admissions into the PGCE program. Communication among the partners of the practical aspect of the program is frequent and highly encouraged. This creates not only a bond between the mentors and the school but also gives the mentors some sense of responsibility (in order to enable them to feel that they are part of the selection and therefore to see the selection process as fair and unbiased). The Ghanaian teacher colleges could learn much from these practices.

\section{What differences emerged from the viewpoints of different participants?}

There seem to be significant differences of opinion about many issues around the mentoring program. Some of these issues are sometimes the expressions of ignorance or signs of confusion amongst the major players on how best the practical aspect of the teacher-training program should be run. From the student trainees' perspective, there is a lack of consistency between some of the major principles, such as the current lesson planning format. For example, the teacher trainees complained that during their "Out" program most of the mentors were not abreast with the current lesson planning format used in the college and so they had a 'difficult' time in convincing the mentors to accept what was already in use. Coincidentally, the mentors also felt the same towards the mentees. This has sometimes resulted in a conflict. It is not, therefore, surprising that teacher trainees sometimes felt that their mentors were expecting too much from them.

The data also suggests that some of the mentors and tutors forget that they have a supporting role to play towards these trainees, especially when they are on teaching practice. The trainee teachers complained that the mentors and or the substantive class teachers act as if the mentees are already qualified teachers when they are in school. This is because they are left on their own by the teachers, causing the trainees to lose confidence in the teachers because the system seems not to have put in place any mechanism to support their development. In addition, there is limited knowledge about the theories of teaching and learning among both the trained teachers and the mentors in schools, resulting in a lack of professionalism among the mentors, who often show inappropriate attitudes and behaviours.

There are issues here that need highlighting. The first point worth noting is that the mentors (and even some tutors) fail to see themselves as agents of change. The fact that mentors and tutors have failed to become agents of change in itself, has blunted the impact of the curriculum reforms as there is little motivation for change in the workplace. They have failed to keep up-to-date with the educational reforms and the speed of change or to engage in the processes which contribute to a better understanding of an educative workplace and school culture (Carter \& Francis, 2001) or to engage the mentees in effective integration and collaborative activities as a way of developing the quality of the experience in the school setting (Ambrosetti \& Dekkers, 2010; Taharally, et al, 1992).

The realisation of this fact by the mentors themselves that they can be change agents in the school setting, could enable them to act as role models for the students, especially during the stage of learning to teach - providing examples of teaching rituals, routines and recipes that can be copied and that will actually work in the classroom. They could also set up opportunities for students to observe them and other teachers at work in the classroom. They may observe and provide feedback on the student teacher's own teaching style and they may work alongside the student teachers, engaging in different forms of collaborative teaching. 'Collaborative teaching, in which the student is party to the teacher's planning and then has some role in teaching and afterwards evaluating the lesson, is particularly powerful. By becoming an 
'insider' to the planning and execution of a lesson, the student has the opportunity to model the teachers teaching at a level of great detail' (Furlong \& Maynard, 1995,_p.184)

Thus, developing on the understanding between mentors and mentees and teachers in schools themselves is essential because there seem to be some confusion with respect to expectations around the mentoring program.

\section{Is the mentoring process fully understood?}

If mentoring is an agency for a life-long change process that enables mentees to acquire 'real life' skills, then it is important that we know how this is achieved. According to Slobodan (1986), real life skills are usually learnt through the aid of some form of coaching. He goes further to argue that the process of coaching requires appropriate feedback on one's practice (which he characterised as 'knowledge of what your actions achieved") and is essential in skill acquisition. Tomlinson (1998) also makes the same point that "The acquisition of practical capability requires cycles of plan-attempt-feedback-replan (p. 13, in Hobson, 2002, p.6). This serves as the premise for the question of whether the teachers in the study really understood the mentoring role (Bozeman \& Feeney, 2007).

Considering the statement made by one of the mentees that, "we are left in the classroom with nobody to consult", "some teachers recognise or pretend to assume that we (mentees) are substitute teachers. Therefore they leave the care of the class entirely in our hands (mentees)". This statement conflicts with the sense of the literature above and suggests that the mentors are not fulfilling their role as active agents and coaches to enable the mentees to acquire the appropriate real life skills needed for successful teaching. This is because, to be involved in active mentoring, i.e. to coach, means being on the spot, and Listening to students; Modelling teaching and general classroom management; Analysing and discussing one's own practice; Observing students; Negotiating with students for their own learning goals; Supporting students as they teach; Encouraging focused observations of classroom events; Encouraging focused student self-assessment; Providing constructive criticism for students; and Highlighting what students can learn from an analysis of practice (Edward \& Collins, 1996, p.28-29) all of which activities were rarely encountered by the students.

Another reason why mentors are failing in their role is that the current practice does not create room for interrogation and reflection on practice. According to Vont (1995), this self interrogation is important in that it forms the main basis for the student teachers to reflect on their experiences in practice. More crucially, the mentor's role underlies this process and the multiple roles that can be assumed by a mentor, suggest that the work of a mentor is complex and multifaceted (Hall et al., 2008) and the type of relationship that is built with a mentee depends on which roles are emphasised (Ambrosetti, \& Dekkers, 2010; Hall et al., 2008). In the educational setting such as in this study, most students (beginning teachers) do not know what to reflect on or how to bring together their practice and valuable theory (Vont, 1995). This means that mentors need to set the conditions that will challenge the students to examine and evaluate the content of the activities that they teach, rather than simply accepting the embedded assumptions about pupils' learning and the underlying subject principles, they need to develop their own subject understanding (Furlong \& Smith, 1996).

Apart from creating room for interrogation and the best conditions for reflection on practice, mentoring (coaching) also means providing support. In relation to this, one mentee said "where I was posted to, there were other social problems that opposed the smooth running of the practice teaching". This comment attests to lack of support and suggests that the mentors appeared to have discounted the fact that social as well as academic aspects of the mentoring 
program are important for mentors and mentees (Heirdsfield, et al., 2008). The lack of support, in addition to the fact that some mentees felt that their supervisors were expecting too much from them and threatened them, echoes the problems outlined by Edwards (1997) in the UK and Sundli (2007) in Norway about differentiating between supervision and mentoring.

Edwards (1997) observed that mentoring in UK teacher education had superseded supervision, with more connotations of caring, modelling, mediation and mothering and less of the authority of supervision. It is clear that if Ghana is to succeed in implementing a good mentoring process, then the process should be defined to reflect the notion of modelling, mediation and mothering. It might also be useful to emulate the case of the Norway where mentors are educated in pedagogical mentoring and in the strategy for mentoring called "promoting reflective thinking". The mentor is expected to be the main link between theory and practice, and the link to the teacher college through skilled and administrative organisational co-operation with teams of teachers at the teachers college (p.207).

What has become apparent from these practices is that, to be able to act as a change agent for the trainees' development, the mentors themselves need careful training so that they are able to provide the right opportunities, and create the best conditions for interrogating and reflecting on practice, since this needs specialised skills and the right knowledge. Mentors need special skills in order to help student teachers with their training (Furlong \& Maynard, 1995). According to Lai (2005) and Wilkins (1992) mentoring involves active processes and in the case of teaching requires student teachers to develop their own teaching skills, insights into their own learning processes and a perspective on themselves as teachers. It also involves the students' consistently exploring their own and other people's practice in order to understand the intellectual, moral and other assumptions on which the learning processes are based. This facilitates continuous learning for both the mentors and teacher trainees.

\section{Conclusion}

This study has explored what the trainee teachers are doing and the roles of the mentors, and tutors. It has identified what seemed to be working and not working with regard to the mentoring and make the following suggestions:

Firstly, there is the need to have a clearer understanding at the college level of the role of universities in the training of teachers.

Secondly, there is a need to have better partnership arrangements with the schools for the effective management of the attachment component. For the effective management of the school attachment component, all of the major players are required to contribute meaningfully by reconsidering the partnerships and what role each partner has to play. They should also consider what essential elements are missing and, therefore, if that element could be performed by any of these players or if there is a need to seek outside help. Equally it is important to strengthen knowledge and skills acquired by the trainees in the various subjects and also consolidate the knowledge and skills gained by the trainee teachers in practical teaching; use University tutors to support the partnership; and articulate the role the college expects the mentors to fulfil in helping to develop teachers.

\section{REFERENCES}


Adegoke, K.A. (2003) Capacity Building of Lead Teacher Training

Institutions in Sub - Saharan Africa: Ghana, UNESCO sponsored project4500007474.

Agbenyega, J., \& Deku, P. (2011). Building new identities in teacher preparation for inclusive education in Ghana. Current Issues in Education, 14(1).4-36 Retrieved from http://cie.asu.edu/

Akyeampong, K. et al (2003) Teacher Training in Ghana-Does it Count?

Multi-Suite Teacher education Research project (MUSTER). London, DFID.

Alexander, R. (1990) Partnership in Initial Teacher Education confronting the issues. In Partnership in Teacher Training (Eds. Booth, Furlong J. Wilkin, M). Cassell, London 59-73

Ambrosetti, A., \& Dekkers, J. (2010). The Interconnectedness of the Roles of Mentors and Mentees in Pre-service Teacher Education Mentoring Relationships. Australian Journal of Teacher Education, 35(6). http://dx.doi.org/10.14221/ajte.2010v35n6.3

Arnstine, D. (1975). Apprenticeship as the miseducation of teachers. Philosophy of Education 1975: Proceedings of the 31st annual meeting of the Philosophy of Education Society (pp. 113-123). San Jose, CA: Society of

Ball, S. J. (1987) Education, Amojism and 'the curriculum of dead' curriculum studies, 1 (.2), 95-21

Bozeman, B., \& Feeney, M.K. (2007). Toward a useful theory of mentoring: A conceptual analysis and critique. Administration \& Society, 39(6), 719-739. http://dx.doi.org/10.1177/0095399707304119.

Calderhead, J. (1989) Reflective teacher and teacher education, Teacher Education $5(1), 43-51$

Carr, W. and Kemmis, S. (1986) Becoming Critical: Educational Knowledge and Actionn Research, Lewes: Falmer/Deakin University Press.

Carter, M. \& Francis, R. (2001). Mentoring and Beginning Teachers' Workplace Learning, Paper presented Oct. 1. the AARE Conference, Sydney, Australia. http://www.aare.edu.au/O0pap/car00232.htm_(accessed 1st January 2008

Christie (2003) "Professional studies in ITE", in Bryce, T. and Humes, W (EDS) Scottish Education second edition Post-Devolution, Edingurgh: University Press.

Cohen L and Manion L (2004) A Guide To teaching Practice $\left(5^{\text {th }}\right.$ edition) London Routledge

Collins, A., Brown, J.S., \& Newman, S.E. (1989). Cognitive apprenticeship: Teaching the crafts of reading, writing, and mathematics. In L.B. Resnick (Ed.), Knowing, learning and instruction (pp. 453-494). Hillsdale, NJ: LEA 
Creswell, J. W. (2003) Research designs Qualitative, quantitative and mixed methods approaches (2nd ed). Thousand Oaks: Sage.

Edwards, A., Gilroy, P. and Hartley, D. (2002) Rethinking Teacher Education: Collaborative Responses to Uncertainty. London: Routledge/Falmer

Elliot, J (1990) 'Competency-based Training and Education of the Profession:

Is a Happy Marriage Possible? Unpublished paper, Norwich: university of East Anglia Centre for Applied Research in Education.

Fairbanks, C. M., Freedman, D. \& Kahn, C. (2000). The role of effective mentors in learning to teach. Journal of Teacher Education, 51(2), 102 -112.

Feiman-Nemser, S. (2003). What new teachers need to learn. Educational Leadership, 60(8), 25-30.

Feiman-Nemser, S. (2000, Fall). Teachers as teacher educators. The New Teacher Center Reflections, 4, 3-7.

Furlong J, Chitty, G. Barrett, E, Barto, L. and Miles, S. (1994). Integration and Partnership in ITT- Dilemma and possibilities. Research paper in Education. 9 (3).

Furlong, J. \& Maynard, T. (1995) Learning to teach and models of mentoring. In K.

Trevor \& A. Shelton Mayes (Eds.) Issues in mentoring. Buckingham UK:

The Open University Press, 10-24.

Furlong, J, Barton, L., Miles, S., Whiting, C., \& Whitty, G. (2000). Teacher Education in Transition. Buckingham, Philadelphia: Open University Press.

Government of Ghana (1992) Constitution for the Fourth Republic of Ghana. Accra. Ghana

Government of Ghana (1995) Ghana Vision 2020 Policy Document. Accra, Ghana.

Hagger H, Burn K, McIntyre D. (1995) The School Mentor Handbook. London: Kogan

Hall, K. M., R. Draper, R. J., Smith, L. K. \& Bullough Jr, R.V. (2008). More than a place to teach: Exploring the perceptions of the roles and responsibilities of mentor teachers'. Mentoring and Tutoring , 16(3), 328-345.

Heirdsfield, A. M., Walker, S., Walsh, K. \& Wilss, L. (2008). Peer mentoring for first-year teacher education students: The mentors experience. Mentoring and Tutoring, 16(2), 109-124.

Hobson, P. (2002) The Cradle of Thought. London, Macmillan

Jessup, G. (1991) Outcomes: NVQs and the Emerging Model of Training Lewes:

Falmer Press

Kuyini, A.B. (2013) Ghana's Education Reform 2007: A realistic proposition or a crisis of vision? Online, International Review of Education DOI 10.1007/s11159-013-9343-7

http://link.springer.com/article/10.1007/s11159-013-9343-7/fulltext.html 
Kuyini, A. B \& Desai. I (2007). Principals' and Teachers' Attitudes and Knowledge of Inclusive Education as Predictors of Effective Teaching practices in Ghana. Journal of Research in Special Educational Needs. 7 (2), 104-113

Kuyini A. B. \& Desai, I. (2008). Providing instruction to students with special needs in inclusive classrooms in Ghana: Issues and challenges. International Journal of Wholeschooling, 4, (1), 22-38

Lai, E. (2005). Mentoring for in-service teachers in a distance teacher education programme:views of mentors, mentees and university teachers. Paper presented at the Australian Association for Research in Education International Education Research Conference, Parramatta.

Lawlor, S (1990) Teachers Mistaught Training, London: Centre for Policy Studies.

Lewin, K. M and Stuart, J.M (2003) Insights into the Policy and Practice of Teacher Education in Low-income Countries: the Multi-Site Teacher Education Project, British Education Research Journal, 29, 5, pp691-707.I

Malderez, A (2001) New ELT professionals, English Teaching Professional, 19, $57-58$

Marshall, K. (1991) 'NVOs: An Assessment of the "Outcomes" Approach to Education and Training ', Journal of Further and Higher Education , 15(3): 50-64

McElvogue, M. \& Salters, M, (1992) 'Models of Competence and Teacher Training Unpublished paper, Belfast: Queen's University, Belfast.

Miller, P \& Cannell, C (1989). Interview in sample survey in Keeves methodology \& Measurement: An international Handbook Oxford.

O'Brien, E., \& Hamburg, I. (2014). Supporting sustainable strategies for SMEs through training, cooperation and mentoring. Higher education studies, 4(2), 61-69. http://dx.doi.org/10.5539/hes.v4n2p61

Odell, S. J., \& Ferraro, D. P. (1992). Teacher Mentoring and Teacher Retention. Journal of Teacher Education, 43(3), 200-204.

O'Hear, A. (1988) Who teaches the teacher? London: Social Affairs Unit.

Schon, D. (1983) The Reflective Practitioner. How professionals Think Action, Basic Books, New York.

Schon D.A (1987) Educating the Reflective Practitioner: San Francisco: Jossey Bass

Slobodan, J. (1986) Acquiring skill, in: Gellatly (Ed.) The skilful mind: An introduction to cognitive psychology, (Milton Keynes, Oxford, University Press.

Smith, A. (2007) Mentoring for experienced school principals: Professional Learning in a safe place. Mentoring and Tutoring, 15 (3), 277-291

Stake . R (1995) The art of case research. Thouasnd Oaks, CA: Sage

Sundli, L (2007) Mentoring-A new mantra for education? Teaching and Teacher Education 23, 201-214

Tomlinson, P (1995) Reflective strategies for school based teacher preparation, open

University Press Buckingham 
Wilkins, M (1992) Mentoring in Schools, London: Kogan Page.

Wilson, J. (1975). Educational theory and the preparation of teachers. Windsor, England: NFER.

Yin, R (1994) Case study research: design and methods. London: Sage. 